\title{
Test Hardware Design for Flightlike Operation of Advanced Stirling Convertors (ASC-E3)
}

Salvatore M. Oriti

Glenn Research Center, Cleveland, Ohio 


\section{NASA STI Program . . . in Profile}

Since its founding, NASA has been dedicated to the advancement of aeronautics and space science. The NASA Scientific and Technical Information (STI) program plays a key part in helping NASA maintain this important role.

The NASA STI Program operates under the auspices of the Agency Chief Information Officer. It collects, organizes, provides for archiving, and disseminates NASA's STI. The NASA STI program provides access to the NASA Aeronautics and Space Database and its public interface, the NASA Technical Reports Server, thus providing one of the largest collections of aeronautical and space science STI in the world. Results are published in both non-NASA channels and by NASA in the NASA STI Report Series, which includes the following report types:

- TECHNICAL PUBLICATION. Reports of completed research or a major significant phase of research that present the results of NASA programs and include extensive data or theoretical analysis. Includes compilations of significant scientific and technical data and information deemed to be of continuing reference value. NASA counterpart of peer-reviewed formal professional papers but has less stringent limitations on manuscript length and extent of graphic presentations.

- TECHNICAL MEMORANDUM. Scientific and technical findings that are preliminary or of specialized interest, e.g., quick release reports, working papers, and bibliographies that contain minimal annotation. Does not contain extensive analysis.

- CONTRACTOR REPORT. Scientific and technical findings by NASA-sponsored contractors and grantees.
- CONFERENCE PUBLICATION. Collected papers from scientific and technical conferences, symposia, seminars, or other meetings sponsored or cosponsored by NASA.

- SPECIAL PUBLICATION. Scientific, technical, or historical information from NASA programs, projects, and missions, often concerned with subjects having substantial public interest.

- TECHNICAL TRANSLATION. Englishlanguage translations of foreign scientific and technical material pertinent to NASA's mission.

Specialized services also include creating custom thesauri, building customized databases, organizing and publishing research results.

For more information about the NASA STI program, see the following:

- Access the NASA STI program home page at http://www.sti.nasa.gov

- E-mail your question to help@sti.nasa.gov

- Fax your question to the NASA STI Information Desk at 443-757-5803

- Phone the NASA STI Information Desk at 443-757-5802

- Write to: STI Information Desk NASA Center for AeroSpace Information 7115 Standard Drive Hanover, MD 21076-1320 
NASA/TM-2012-217726

AIAA-2012-4254

\section{Test Hardware Design for Flightlike Operation of Advanced Stirling Convertors (ASC-E3)}

Salvatore M. Oriti

Glenn Research Center, Cleveland, Ohio

Prepared for the

10th International Energy Conversion Engineering Conference (IECEC)

sponsored by the American Institute of Aeronautics and Astronautics

Atlanta, Georgia, July 30-August 1, 2012

National Aeronautics and

Space Administration

Glenn Research Center

Cleveland, Ohio 44135 


\section{Acknowledgments}

This work is funded through the NASA Science Mission Directorate.

Trade names and trademarks are used in this report for identification only. Their usage does not constitute an official endorsement, either expressed or implied, by the National Aeronautics and Space Administration.

Level of Review: This material has been technically reviewed by technical management.

Available from

NASA Center for Aerospace Information 7115 Standard Drive

Hanover, MD 21076-1320
National Technical Information Service 5301 Shawnee Road Alexandria, VA 22312

Available electronically at http://www.sti.nasa.gov 


\title{
Test Hardware Design for Flightlike Operation of Advanced Stirling Convertors (ASC-E3)
}

\author{
Salvatore M. Oriti \\ National Aeronautics and Space Administration \\ Glenn Research Center \\ Cleveland, Ohio 44135
}

\begin{abstract}
NASA Glenn Research Center (GRC) has been supporting development of the Advanced Stirling Radioisotope Generator (ASRG) since 2006. A key element of the ASRG project is providing life, reliability, and performance testing of the Advanced Stirling Convertor (ASC). For this purpose, the Thermal Energy Conversion branch at GRC has been conducting extended operation of a multitude of free-piston Stirling convertors. The goal of this effort is to generate long-term performance data (tens of thousands of hours) simultaneously on multiple units to build a life and reliability database. The test hardware for operation of these convertors was designed to permit in-air investigative testing, such as performance mapping over a range of environmental conditions. With this, there was no requirement to accurately emulate the flight hardware. For the upcoming ASC-E3 units, the decision has been made to assemble the convertors into a flight-like configuration. This means the convertors will be arranged in the dual-opposed configuration in a housing that represents the fit, form, and thermal function of the ASRG. The goal of this effort is to enable system level tests that could not be performed with the traditional test hardware at GRC. This offers the opportunity to perform these system-level tests much earlier in the ASRG flight development, as they would normally not be performed until fabrication of the qualification unit. This paper discusses the requirements, process, and results of this flight-like hardware design activity.
\end{abstract}

\section{Nomenclature}

$\begin{array}{ll}\text { ASC } & \text { Advanced Stirling Convertor } \\ \text { ASRG } & \begin{array}{l}\text { Advanced Stirling Radioisotope Generator } \\ \text { beginning of mission }\end{array} \\ \text { BOM } & \text { Department of Energy } \\ \text { DOE } & \begin{array}{l}\text { end of mission } \\ \text { EOM }\end{array} \\ \text { EMI } & \text { electromagnetic interference } \\ \text { EU } & \text { engineering unit } \\ \text { GRC } & \text { NASA Glenn Research Center } \\ \text { GPHS } & \text { General Purpose Heat Source } \\ \text { IV\&V } & \text { independent verification and validation } \\ \text { LMCT } & \text { Lockheed Martin Coherent Technologies } \\ \text { LMSS } & \text { Lockheed Martin Space Systems } \\ \text { LR } & \text { low rejection } \\ \text { HR } & \text { high rejection } \\ \text { SRG-110 } & \text { Stirling Radioisotope Generator, 110-W } \\ \text { TDC } & \text { Technology Demonstration Convertor }\end{array}$




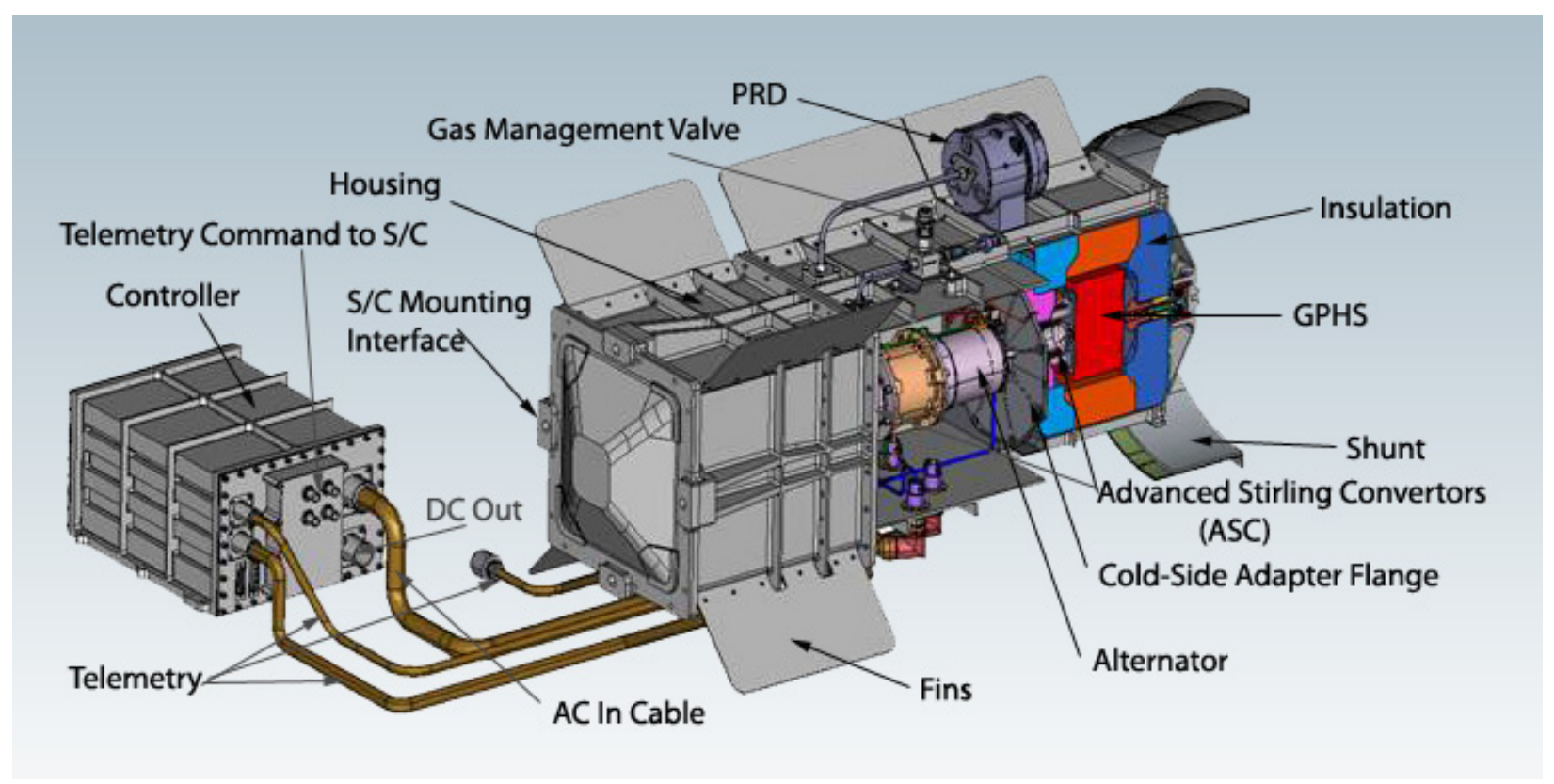

Figure 1.-ASRG flight unit.

\section{Introduction}

The Thermal Energy Conversion Branch at NASA Glenn Research Center (GRC) has been supporting the development of the Advanced Stirling Radioisotope Generator (ASRG). The ASRG (Figure 1) has been identified for use on two of the three candidate Discovery 12 missions (Ref. 1). A key element of the ASRG project is providing life, reliability, and performance data for Sunpower's Advanced Stirling Convertor (ASC). For this purpose, GRC has established a laboratory that is conducting extended operation of several ASCs (Ref. 2). The goal of this effort is to generate performance data over a sufficiently long period of time (tens of thousands of hours) to support probabilistic reliability analyses. As of May 2012, a total of 214,000 hr have been accumulated on 24 convertors. This hardware set spans the history of Sunpower's ASC technology development, and includes developmental units such as ASC-0s, ASC-Es (engineering unit convertors), and the most recent ASC-E2s.

The next set of hardware, deemed ASC-E3, will also be hermetically sealed and capable of $850{ }^{\circ} \mathrm{C}$ hot-end temperature operation, similar to the ASC-E2. The convertors are being produced to the flight unit drawings and quality practices, and as such will exercise the fabrication process planned for the ASRG flight unit convertors. However, they will not be installed in any qualification or flight level generator. Instead, they will be used for extended operation and controller testing. In the past, GRC extended operation test articles have not been designed to emulate the flight unit hardware, but instead provide the capability to simulate a range of operating conditions. An example of an ASC-E2 test station is shown in Figure 2. For the ASC-E3s, the decision has been made to tailor the extended operation hardware such that it emulates the ASRG flight unit. This provides the opportunity for executing systemlevel tests that would normally not be possible until the production of the ASRG qualification unit. In effect, the activity will integrate the high-value ASC-E3 hardware into assemblies that will each provide the same thermal functionality as an ASRG engineering unit (EU). The controller will not initially be included in the ASC-E3 flightlike configuration at GRC. The option exists for future use of the controller. 


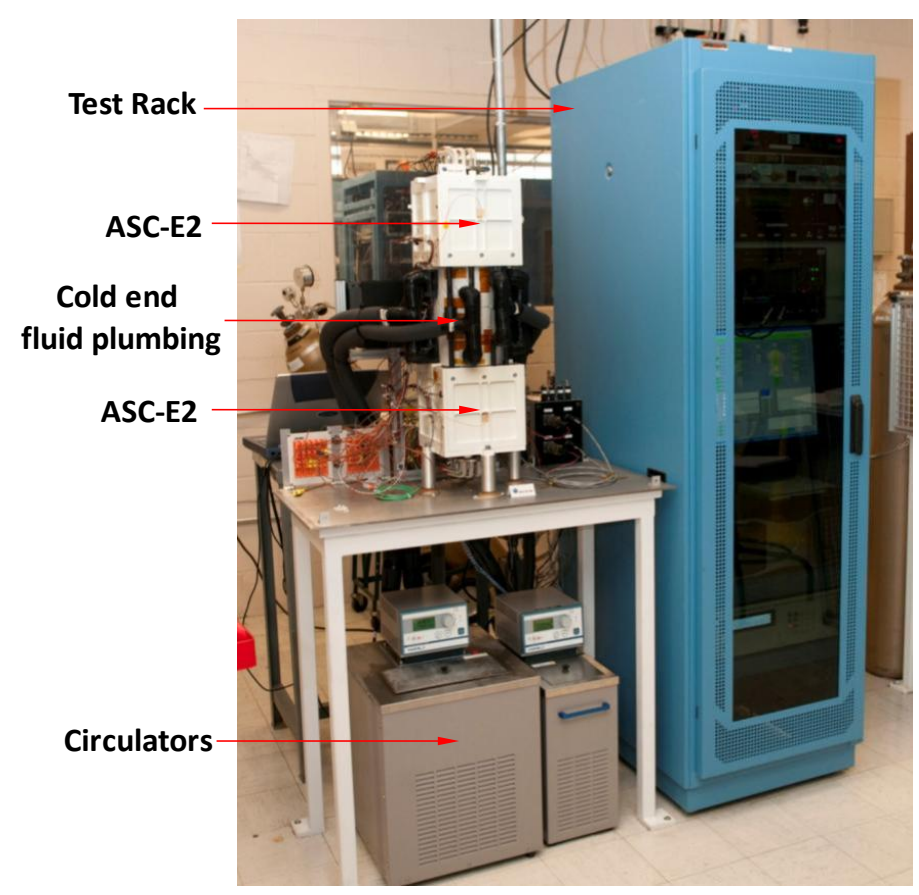

Figure 2.-Example ASC-E2 test station at GRC.

\section{Design Guidelines}

The test hardware designed for ASC-E2 operation differs from a flight generator in several ways. While the housing was made to aesthetically resemble the flight generator, the housing is not used as the heat rejection device for the Stirling cycle. The ASC-E2 test stations at GRC utilize fluid circulators coupled to a rejection device attached directly to the cold end of the convertor to effect a cold-end temperature control method. Notice in Figure 2 the presence of fluid plumbing that enters the center of the test article. This was necessary to achieve precise, independent temperature control of the cold end and alternator housing of the convertors, which was necessary for performance mapping at several different operating scenarios expected during a mission, as well as qualification temperatures. On the flight unit, the cold-end temperature is a function of the sink temperature, and the conduction path provided by the cold-side adapter flange (CSAF) on the convertor and the ASRG housing. Also, the mechanical coupling of the two dual-opposed convertors was not designed to match the ASRG. Instead, the coupling was achieved by four connecting rods between the two insulation containments, in addition to the interconnect tube joining the two convertor alternator housings. Also, the current hardware was not designed to provide a sealed inert argon environment around the convertors, which is achieved in the flight design.

For the design of GRC's ASC-E3 extended operation hardware, the guiding principle was to duplicate all the design features of the flight unit where possible. The design concept for GRC's flight-like housing is shown in Figure 3. Notice that all external features have been duplicated. The Lockheed Martin drawings for the ASRG flight unit in the electrically-heated configuration were used for this effort. The outer surface will be identical to the ASRG flight unit, including the length of the fins. The same electrical feedthroughs will be used to pass power and signals through the housing. Some design features were sacrificed to reduce cost and complexity. These deviations include the use of aluminum for the housing instead of beryllium, and a different electric heat source to emulate the radioisotope fuel. Other less-significant deviations are as follows. The pressure relief device was eliminated since this hardware will not experience ascent through the atmosphere. Instead, a gas port will be located where the relief device tube would normally enter the housing. A remotely-located shunt dissipator unit will be utilized in lieu of one that attaches to the housing. However, the option for attachment of a shunt remains, should the lieu of one that attaches to the housing. However, the option for attachment of a shunt remains, should the 


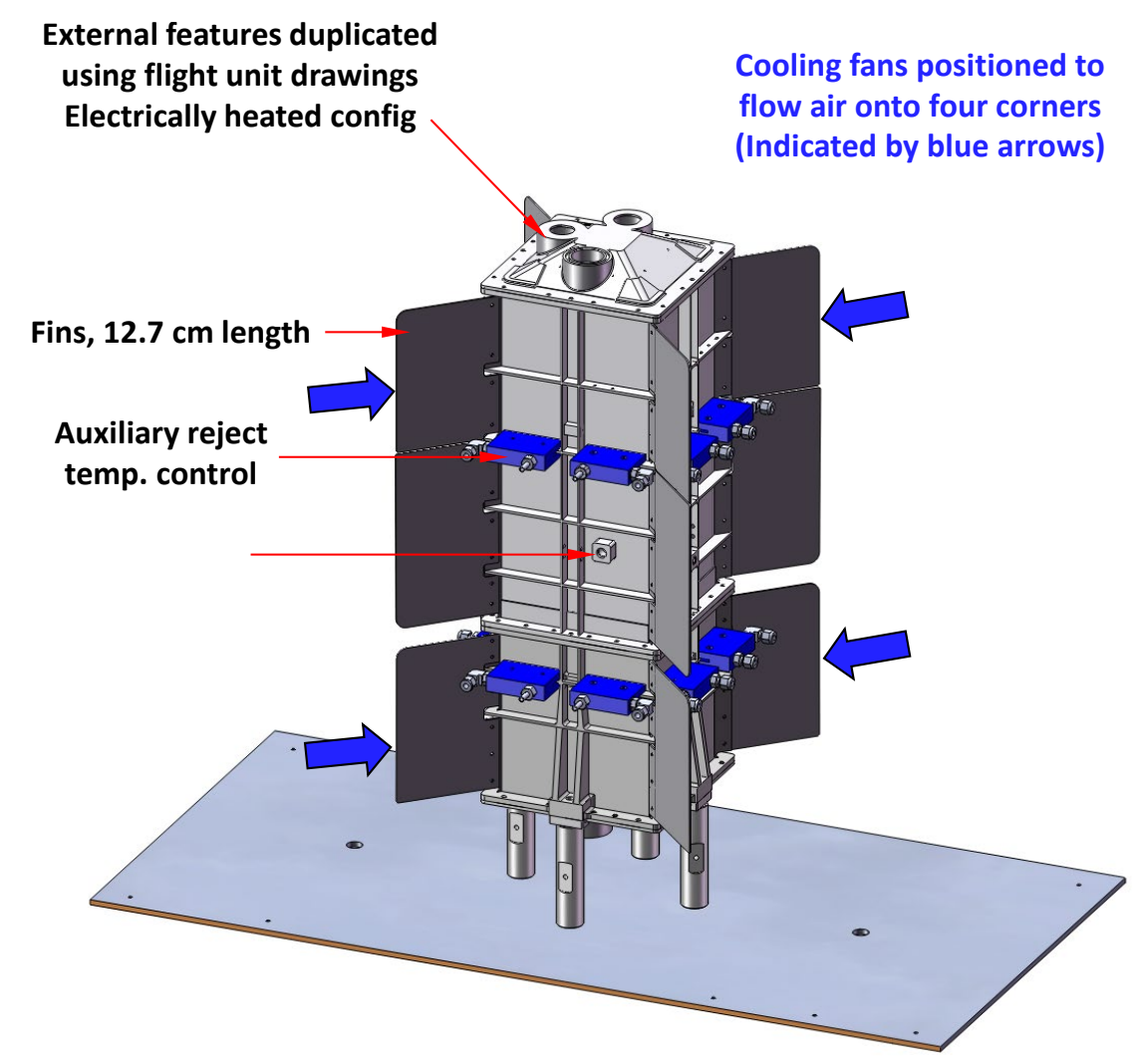

Figure 3.-Concept for extended operation of ASC-E3s in flightlike configuration. Convertors will be installed in housing that provides cooling via conduction (top). Housing outer surface will be cooled by forced convection.

decision be made to install one at a later time. A type of white paint has been chosen in lieu of the surface coating of the flight unit. This paint will be thermally equivalent, as it will achieve the same emissivity, but will be simpler and less costly to apply, and have less restrictive handling procedures. The GRC design also includes auxiliary temperature control devices, shown as the blue blocks with fluid fittings in Figure 3. These can be attached to the housing rib surfaces as needed, if certain tests require temperature control not achievable with forced-air convection alone. The auxiliary temperature control blocks also serve the purpose of increasing thermal mass of the test article as will be described in a later section. The test article will be capable of operation without these auxiliary temperature control blocks. Internally, but not shown in the figure, the stud that applies the preload to the heat source was simplified to a single ceramic piece. The details of the GRC-designed electric heat source will be discussed in a later section. These guidelines were formed with a focus on duplicating the thermal behavior of the ASRG. No requirements were set for duplicating mass or dynamic characteristics.

\section{Aluminum Versus Beryllium Housing}

Aluminum 6061 was chosen for the GRC flight-like housing because of its low cost, ease of machining, and wide availability. Comparatively, beryllium is expensive and requires machining safety practices beyond that necessary for aluminum. Aluminum has a sufficiently high thermal conductivity to make it useful for this purpose, but has a higher density than beryllium. This means an aluminum housing will be higher mass than the ASRG flight unit. This was deemed acceptable, as the primary purpose of this design is to emulate the thermal behavior of the ASRG flight unit. No tests are planned that will require the same total system mass. With this decision, the effect of aluminum in place of beryllium needed to be quantified. Table I summarizes the key material properties useful for this purpose. 
TABLE I.-APPLICABLE MATERIAL PROPERTY DIFFERENCES BETWEEN ALUMINUM AND BERYLLIUM.

\begin{tabular}{|l|c|c|}
\cline { 2 - 3 } \multicolumn{1}{c|}{} & $\begin{array}{c}\text { Aluminum } \\
6061 \mathrm{~T} 6\end{array}$ & $\begin{array}{c}\text { Beryllium } \\
\text { (ASRG) }\end{array}$ \\
\hline Density, $\mathrm{g} / \mathrm{cm}^{3}$ & 2.7 & 1.85 \\
\hline Thermal conductivity, W/mK & 167 & 187 \\
\hline Volumetric heat capacity, $\mathrm{kJ} / \mathrm{K} / \mathrm{m}^{3}$ & 2420 & 3470 \\
\hline Coefficient of thermal expansion, $\mathrm{ppm} / \mathrm{K}$ & 23 & 12 \\
\hline
\end{tabular}

Aluminum alloy $6061 \mathrm{~T} 6$ has 12 percent lower thermal conductivity than the particular beryllium alloy chosen for the ASRG flight unit. To make the housing thermally equivalent, the thermal resistances that the rejected heat encounters were maintained by increasing the thickness of the conduction paths by 12 percent. This included the thickness of the bulkhead that attaches to the CSAF, the wall-thickness of the housing, and the thickness of the fins. The changes in thickness were made such that the internal square dimensions were duplicated, and the extra 12 percent was added to the outer surface of the housing dimensions. For the purpose of duplicating transient thermal behavior, the heat capacity of the two materials was evaluated. Aluminum has a significantly lower volumetric heat capacity. This is true despite the fact that aluminum has higher mass density than beryllium. Thus, a direct material replacement would result in an inadequately low heat capacity of the test article, even after the additional 12 percent thickness. The solution to this is to attach extra thermal mass to the external surface of the housing at axial locations corresponding to each convertor's rejection flange. Aluminum blocks with dimensions 1.25 by 1.25 by 6.5 inches will constitute the required thermal mass. These same blocks will be used to provide the option for auxiliary temperature control via fluid flow. They will be attached to the ribs of the housing as shown in Figure 3. The location of these attachment points is as close as possible to the CSAF attachment location. With this arrangement, the overall thermal resistance will be maintained, because the blocks are not in the heat rejection conduction path, but the rejected heat will be absorbed by the extra thermal mass. This will result in a total system transient response that emulates the flight unit.

Aluminum also exhibits almost twice the thermal expansion of beryllium. To evaluate the effect of this, the forces on the convertor induced by differential thermal expansion of the convertor pair and the housing were calculated and compared to those of a beryllium housing. A linear thermal expansion model was created (Figure 4) to calculate the forces induced by differential expansion. Included was the convertor alternator housings, the convertor heater heads, the heat sources, and the housing sections. The stiffnesses of the CSAFs and heat source spring preload were used to then calculate forces that develop when the convertor and housing change temperatures. Several thermal scenarios were analyzed that represented the range of expected temperatures. The results of the lowest and highest sink temperature conditions are summarized in Table II. This table contains results of the simulation in which only the beryllium is substituted with aluminum. The interconnect tube in this case was the same material and length as the ASRG. The temperatures of the various components were calculated at these sink temperature scenarios, and input into the model to calculate forces. The calculations show that at the lowest sink temperature scenario, the induced force is 20 percent greater if using an aluminum housing. However, this is not of a magnitude expected to disrupt convertor operation. The convertor will be exposed to forces higher than those calculated here during product specification verification tests. The other cases, such as nominal in-air operation in a laboratory environment, fall between the two extremes shown in Table II. The interconnect tube material or length can be altered to skew the generated forces, but only one thermal condition can be made to match the ASRG. 


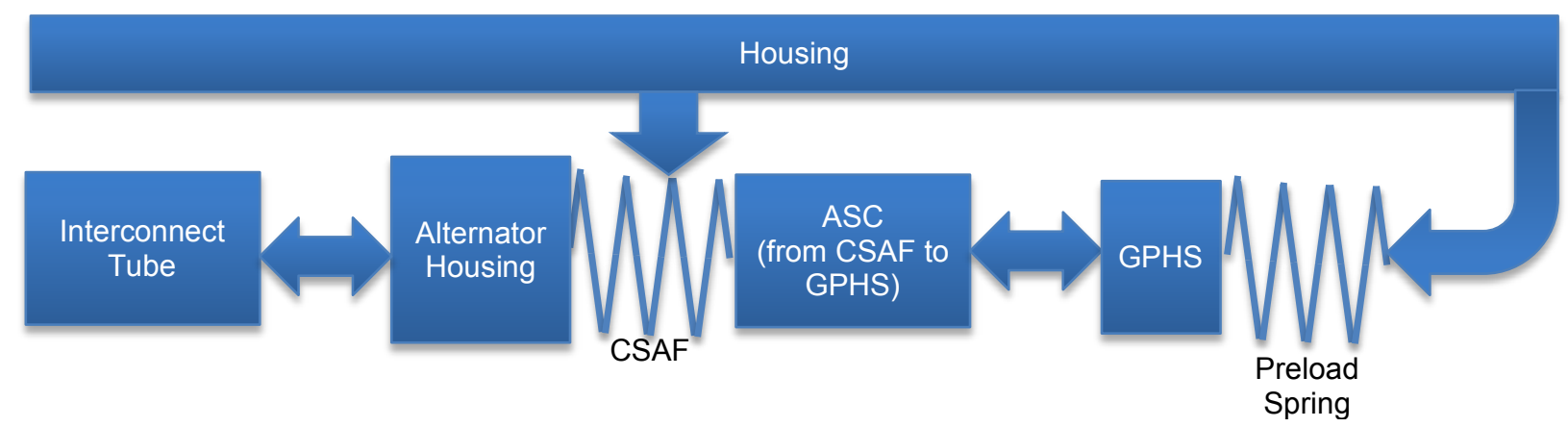

Figure 4.-Linear thermal expansion model for calculating effect of aluminum housing on convertor mounting forces.

TABLE II.-COMPARISON OF THERMALLY INDUCED FORCES

ON THE CONVERTOR FOR ALUMINUM AND BERYLLIUM

HOUSINGS AT TWO SINK TEMPERATURE ENVIRONMENTS

\begin{tabular}{|l|c|c|}
\cline { 2 - 3 } \multicolumn{1}{c|}{ HOUSINGS AT TWO SINK TEMPERATURE ENVIRONMENTS } & \multicolumn{2}{|c|}{$\begin{array}{c}\text { Thermally induced } \\
\text { force on convertor, } \\
\text { At Deep Space Sink Temp }\end{array}$} \\
\cline { 2 - 3 } & Beryllium & Aluminum \\
\hline At Near Earth Sink Temp & -80 & 173 \\
\hline
\end{tabular}

\section{Electric Heat Source}

The decision has been made to also deviate from the flight unit's ground testing electric heat source. This was done to reduce cost and improve life expectancy for in-air operation. Building on past experience with high-temperature convertor operation, GRC devised the heat source concept depicted in Figure 5. The design consists of cartridge heaters brazed into a nickel 201 block which duplicates the outer surface geometry of the General Purpose Heat Source (GPHS) module. The heat source was designed to maximize life by maximizing cartridge contact area to minimize heat flux, and reducing thermal resistance. Brazing reduces the thermal resistance between the cartridge sheath and the nickel block. The effect of these tactics is to reduce the internal element temperature which ultimately governs life of the heater. Since the GPHS module has no electrical lead requirement, and thus no thermal conduction loss associated with this, the goal of this electric heat source was to minimize the conduction losses due to the electrical leads. The cartridge heaters will be connected electrically in parallel by spotwelded nickel bus wiring. The parallel connection between the cartridges will reside inside the thermal insulation. This requires only two protrusions through the insulation: one positive lead, and one negative lead. One disadvantage of a nickel 201 block of this geometry is that it will have significantly higher heat capacity than the GPHS module. The desire is for the heat source to have a similar heat capacity, so that the transient thermal response will be accurately emulated. Other options are being entertained that will more closely match the GPHS module thermal mass. Both a material and geometry change are required to reduce the heat capacity of the electric heat source sufficiently. A material substitution to molybdenum, and a geometry change to that shown in Figure 5, would achieve the desired effect. The outer surface geometry should be maintained so that the heat transfer from source to insulation emulates the GPHS module in the ASRG assembly. 


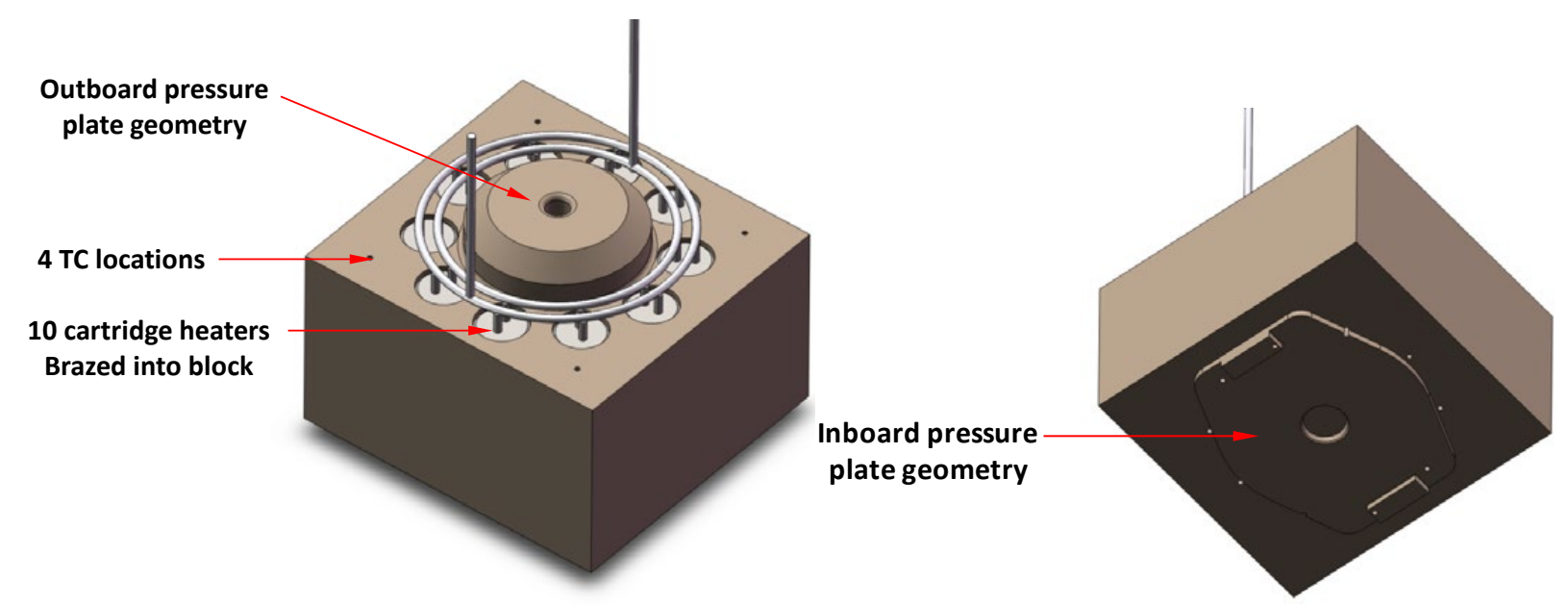

Figure 5.-Design concept of a long-life electric heat source for extended operation in the flight-like housing.

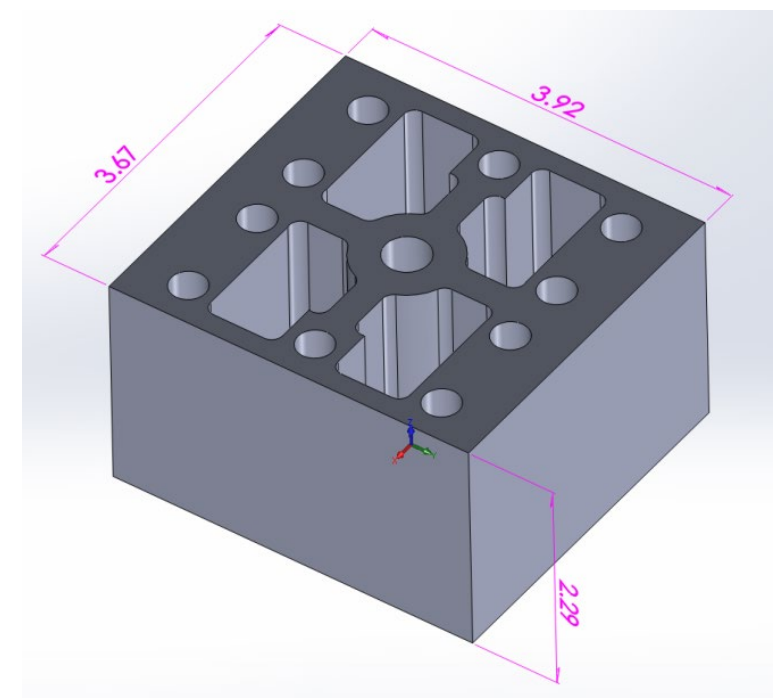

Figure 6.-Alternative design of electric heat source that more closely matches heat capacity of a GPHS module. (Dimensions in centimeters)

\section{Test Plans}

A series of tests are planned to utilize the hardware, including independent verification and validation (IV\&V), characterization tests, and life certification. The design of this hardware enables unique tests that would normally not be capable until a qualification ASRG unit. Planned tests include:

- Performance mapping with controller in air, and thermal vacuum

- Performance characterization with controller and changes in AC bus voltage, net heat input, and sink temperature

- Demonstration of argon venting in thermal vacuum.

- Quantifying effect of thermal imbalance, such as one side shaded while the other side is exposed to the Sun

- Practice fueling process on fully-operable convertors 
In addition to these tests, the convertors will undergo extended operation in the flight-like configuration. This mode of operation will be the same as that implemented on the other ASCs currently operating in the laboratory.

\section{Conclusion}

GRC is preparing facilities for extended operation of several ASC-E3 units. A housing has been designed that emulates the ASRG flight generator, but is made of aluminum instead of beryllium. The effect of differing material properties has been accounted for to achieve similar thermal behavior as the flight unit. Design decisions were made to make the aluminum housing match the ASRG flight beryllium housing thermal conduction and heat capacity. The inside dimensions and interfaces to the convertors were not altered. Thicknesses that serve as conduction paths were increased by 12 percent to match thermal resistance. Auxiliary mass was added to match heat capacity, and provide the option for temperature control. The effect of higher thermal expansion of aluminum was analyzed and quantified. Results of this analysis showed that the effect can be tolerated. A long-life electric heat source has also been designed that uses relatively low-cost cartridge heaters. GRC is currently developing a research plan for this hardware that will include system level tests such as thermal vacuum operation in addition to extended operation.

\section{References}

1. NASA Discovery Program Mission News. http://discovery.nasa.gov/news/index.cfml? ID=1034, accessed November 9, 2012.

2. Oriti, S.M. (2011). Extended Operation of Stirling Convertors at NASA Glenn Research Center. AIAA-2011-5726. 



\begin{tabular}{|c|c|c|c|c|c|}
\hline \multicolumn{5}{|c|}{ REPORT DOCUMENTATION PAGE } & $\begin{array}{l}\text { Form Approved } \\
\text { OMB No. 0704-0188 }\end{array}$ \\
\hline \multicolumn{6}{|c|}{$\begin{array}{l}\text { The public reporting burden for this collection of information is estimated to average } 1 \text { hour per response, including the time for reviewing instructions, searching existing data sources, gathering and maintaining the } \\
\text { data needed, and completing and reviewing the collection of information. Send comments regarding this burden estimate or any other aspect of this collection of information, including suggestions for reducing this } \\
\text { burden, to Department of Defense, Washington Headquarters Services, Directorate for Information Operations and Reports (0704-0188), } 1215 \text { Jefferson Davis Highway, Suite } 1224 \text {, Allington, VA } 222202-402 \text {. } \\
\text { Respondents should be aware that notwithstanding any other provision of law, no person shall be subject to any penalty for failing to comply with a collection of information if it does not display a currently valid OMB } \\
\text { control number. } \\
\text { PLEASE DO NOT RETURN YOUR FORM TO THE ABOVE ADDRESS. }\end{array}$} \\
\hline \multicolumn{2}{|c|}{$\begin{array}{l}\text { 1. REPORT DATE (DD-MM-YYYY) } \\
01-11-2012\end{array}$} & \multicolumn{3}{|c|}{$\begin{array}{l}\text { 2. REPORT TYPE } \\
\text { Technical Memorandum }\end{array}$} & 3. DATES COVERED (From - To) \\
\hline \multirow{3}{*}{\multicolumn{5}{|c|}{$\begin{array}{l}\text { 4. TITLE AND SUBTITLE } \\
\text { Test Hardware Design for Flightlike Operation of Advanced Stirling Convertors (ASC-E3) }\end{array}$}} & 5a. CONTRACT NUMBER \\
\hline & & & & & 5b. GRANT NUMBER \\
\hline & & & & & 5c. PROGRAM ELEMENT NUMBER \\
\hline \multirow{3}{*}{\multicolumn{5}{|c|}{$\begin{array}{l}\text { 6. AUTHOR(S) } \\
\text { Oriti, Salvatore, M. }\end{array}$}} & 5d. PROJECT NUMBER \\
\hline & & & & & 5e. TASK NUMBER \\
\hline & & & & & $\begin{array}{l}\text { 5f. WORK UNIT NUMBER } \\
\text { WBS } 138494.01 .99 .01\end{array}$ \\
\hline \multicolumn{5}{|c|}{$\begin{array}{l}\text { 7. PERFORMING ORGANIZATION NAME(S) AND ADDRESS(ES) } \\
\text { National Aeronautics and Space Administration } \\
\text { John H. Glenn Research Center at Lewis Field } \\
\text { Cleveland, Ohio 44135-3191 }\end{array}$} & $\begin{array}{l}\text { 8. PERFORMING ORGANIZATION } \\
\text { REPORT NUMBER } \\
\text { E-18224 }\end{array}$ \\
\hline \multirow{2}{*}{\multicolumn{5}{|c|}{$\begin{array}{l}\text { 9. SPONSORING/MONITORING AGENCY NAME(S) AND ADDRESS(ES) } \\
\text { National Aeronautics and Space Administration } \\
\text { Washington, DC 20546-0001 }\end{array}$}} & $\begin{array}{l}\text { 10. SPONSORING/MONITOR'S } \\
\text { ACRONYM(S) } \\
\text { NASA }\end{array}$ \\
\hline & & & & & $\begin{array}{l}\text { 11. SPONSORING/MONITORING } \\
\text { REPORT NUMBER } \\
\text { NASA/TM-2012-217726 }\end{array}$ \\
\hline \multicolumn{6}{|c|}{$\begin{array}{l}\text { 12. DISTRIBUTION/AVAILABILITY STATEMENT } \\
\text { Unclassified-Unlimited } \\
\text { Subject Category: } 20 \\
\text { Available electronically at http://www.sti.nasa.gov } \\
\text { This publication is available from the NASA Center for AeroSpace Information, 443-757-5802 }\end{array}$} \\
\hline \multicolumn{6}{|c|}{ 13. SUPPLEMENTARY NOTES } \\
\hline \multicolumn{6}{|c|}{$\begin{array}{l}\text { 14. ABSTRACT } \\
\text { NASA Glenn Research Center (GRC) has been supporting development of the Advanced Stirling Radioisotope Generator (ASRG) since 2006. A key element of the ASRG } \\
\text { project is providing life, reliability, and performance testing of the Advanced Stirling Convertor (ASC). For this purpose, the Thermal Energy Conversion branch at GRC has } \\
\text { been conducting extended operation of a multitude of free-piston Stirling convertors. The goal of this effort is to generate long-term performance data (tens of thousands of } \\
\text { hours) simultaneously on multiple units to build a life and reliability database. The test hardware for operation of these convertors was designed to permit in-air investigative } \\
\text { testing, such as performance mapping over a range of environmental conditions. With this, there was no requirement to accurately emulate the flight hardware. For the } \\
\text { upcoming ASC-E3 units, the decision has been made to assemble the convertors into a flight-like configuration. This means the convertors will be arranged in the dual-opposed } \\
\text { configuration in a housing that represents the fit, form, and thermal function of the ASRG. The goal of this effort is to enable system level tests that could not be performed } \\
\text { with the traditional test hardware at GRC. This offers the opportunity to perform these system-level tests much earlier in the ASRG flight development, as they would normally } \\
\text { not be performed until fabrication of the qualification unit. This paper discusses the requirements, process, and results of this flight-like hardware design activity. }\end{array}$} \\
\hline \multicolumn{6}{|c|}{$\begin{array}{l}\text { 15. SUBJECT TERMS } \\
\text { Radioisotope; ASRG; Stirling; Energy conversion; ASC }\end{array}$} \\
\hline \multicolumn{3}{|c|}{ 16. SECURITY CLASSIFICATION OF: } & $\begin{array}{l}\text { 17. LIMITATION OF } \\
\text { ABSTRACT }\end{array}$ & $\begin{array}{l}\text { 18. NUMBER } \\
\text { OF }\end{array}$ & $\begin{array}{l}\text { 19a. NAME OF RESPONSIBLE PERSON } \\
\text { STI Help Desk (email:help } @ \text { sti.nasa.gov) }\end{array}$ \\
\hline $\begin{array}{l}\text { a. REPORT } \\
\text { U }\end{array}$ & $\begin{array}{l}\text { b. ABSTRACT } \\
\text { U }\end{array}$ & $\begin{array}{l}\text { c. THIS } \\
\text { PAGE } \\
\text { U }\end{array}$ & UU & $\begin{array}{l}\text { PAGES } \\
16\end{array}$ & $\begin{array}{l}\text { 19b. TELEPHONE NUMBER (include area code) } \\
443-757-5802\end{array}$ \\
\hline
\end{tabular}



